\title{
18. Working at the edges of legal protection: Equality law and youth work experience from a comparative perspective $^{1}$
}

\author{
Alysia Blackham
}

\subsection{INTRODUCTION}

Youth work experience occupies the edges of legal protection, generally falling beyond the scope of established labour law. While there is growing academic and regulatory consideration of how youth work experience might be regulated, and how it might best be categorized, ${ }^{2}$ these discussions have rarely encompassed equality law in any depth. ${ }^{3}$ This is surprising, as equality law could have particular significance for those undertaking work experience or other forms of unpaid labour. Drawing on comparative legal doctrinal analysis of the law in Australia and the United Kingdom (UK), with a particular focus on Great Britain (GB), this chapter considers the extent to which unpaid work experience is likely to be covered by equality law. It considers the potential relevance of equality law to work experience (section 18.2), then canvasses the scope of equality law in Australia and the UK, and the extent to which it might protect or exclude those undertaking work experience in various forms (section 18.3). Issues of enforcement are flagged in section 18.4, and section 18.5 concludes.

\footnotetext{
1 This research was funded by the Australian Government through the Australian Research Council's Discovery Projects funding scheme (DE170100228). The views expressed herein are those of the author and are not necessarily those of the Australian Government or Australian Research Council.

2 Andrew Stewart and Rosemary Owens, Experience or Exploitation? The Nature, Prevalence and Regulation of Unpaid Work Experience, Internships and Trial Periods in Australia (Fair Work Ombudsman 2013).

3 Though, in relation to work-integrated learning, see Anne Hewitt, Rosemary Owens and Andrew Stewart, 'Mind the Gap: Is the Regulation of Work-Integrated Learning in Higher Education Working?' (2018) 44 Monash UL Rev 234.
} 


\subsection{THE RELEVANCE OF EQUALITY LAW TO YOUTH WORK EXPERIENCE}

Equality law could have substantial relevance to those undertaking unpaid work experience. First, for those with a disability, the ability to obtain reasonable adjustments in the workplace can make the difference between success and struggle in a trial position. ${ }^{4}$ Reasonable accommodations understandably improve employee retention for those with disabilities, ${ }^{5}$ and reflect a social and organizational obligation to address discrimination. ${ }^{6}$ Access to reasonable adjustments, as provided for under equality law, is fundamental for those with a disability undertaking unpaid work experience, and necessary to ensure they are able to effectively participate in the workplace.

Second, given those undertaking unpaid work experience are more likely to be young ${ }^{7}$ and comparatively inexperienced at work, and occupying temporary and vulnerable work positions, there are likely to be substantial situational power differentials in the workplace. This puts those undertaking unpaid work experience at risk of sexual harassment and other forms of discrimination at work. ${ }^{8}$ Indeed, in the USA, a 2018 survey of former interns found that the vast majority of the 22 respondents ( 82 per cent) had been aware of their colleagues experiencing sexual harassment, and half had personally experienced sexual harassment in their internships. ${ }^{9}$ There is growing recognition that many well-known interns - such as Monica Lewinsky - have been subjected to a

4 See generally Catherine Elizabeth Georgiou, Shima Espahbodi and Lorraine Hilary De Souza, 'Preparing for the World of Work: An Exploratory Study of Disabled Students' Experiences of Work Placement' (2012) 25 J Educ \& Work 523.

5 Richard V Burkhauser, JS Butler and Yang Woo Kim, 'The Importance of Employer Accommodation on the Job Duration of Workers with Disabilities: A Hazard Model Approach' (1995) 2 Lab Econ 109.

6 Sharon L Harlan and Pamela M Robert, 'The Social Construction of Disability in Organizations: Why Employers Resist Reasonable Accommodation' (1998) 25 Work \& Occupations 397, 398.

7 Damian Oliver, Paula McDonald, Andrew Stewart and Anne Hewitt, Unpaid Work Experience in Australia: Prevalence, Nature and Impact (Department of Employment 2016) 5, 24, https://www.ag.gov.au/sites/default/files/2020-03/unpaid _work_experience_report_-_december_2016.pdf, accessed 30 March 2021.

8 Alexandra Natale, 'Why Sexually Harassed Interns Can’t Fight Back' (Mic, 27 August 2013), https://mic.com/articles/60377/why-sexually-harassed-interns-can-t -fight-back, accessed 30 March 2021.

9 BA Rudolph Foundation, Rise Up: Interns, Their Workplace Rights, and the Tools to End Sexual Harassment (BA Rudolph Foundation 2018), https://empowherwomen .org/wp-content/uploads/2019/10/RISE-UP-White-Paper-and-Fact-Sheet-Final-for -Release-June-26-2018.pdf, accessed 30 March 2021. 
'gross abuse of power' in the workplace. ${ }^{10}$ Thus, existing protections for those undertaking internships or work experience are of growing importance to public discussion and discourse.

Third, there is concern that individuals have disparate access to unpaid work experience, particularly when it is obtained through personal or familial connections. In Oliver and others' Australian survey of 3800 respondents, many young people (29.3 per cent of those aged 18 to 29 years) organized work experience through a family member, friend or someone in their personal network. ${ }^{11}$ The likelihood of participating in unpaid work experience also increased with respondents' socio-economic status. ${ }^{12}$ Fifty-nine per cent of those who undertook unpaid work experience said that they found their experience helpful for finding paid employment. ${ }^{13}$ This raises questions about the extent to which participating in unpaid work experience impairs social mobility, especially if access is closed off to those from non-traditional backgrounds who do not have access to strong personal networks. In a labour market where there is growing competition to obtain and retain work, participating in unpaid work experience may offer individuals a substantial competitive edge. Given not everyone has access to these opportunities, ${ }^{14}$ this flags major issues for discrimination and equality law, particularly if access to work experience is a gateway to later paid employment: discrimination in work experience may have flow-on effects that affect the labour market as a whole. ${ }^{15}$

The negative social consequences of unpaid internships are becoming a focal point of law reform in the UK. ${ }^{16}$ The risks of unpaid internships were recognized in the Taylor Review of Modern Working Practices, which described them as 'an abuse of power by employers and extremely damaging to social mobility'. ${ }^{17}$ The Taylor Review found, however, that there was no

10 Associated Press, 'Monica Lewinsky Says Bill Clinton Affair Was "Gross Abuse of Power" The Guardian (London, 2 February 2018), http://www.theguardian .com/us-news/2018/feb/27/monica-lewinsky-says-bill-clinton-affair-was-gross-abuse -of-power, accessed 30 March 2021.

11 Oliver and others (n 7) 36.

12 Ibid 5, 24.

13 Ibid 9, 50 .

14 International Labour Organization (ILO), Global Employment Trends for Youth 2013: A Generation at Risk (ILO 2013) 64.

15 See eg Andrew Francis and Hilary Sommerlad, 'Access to Legal Work Experience and Its Role in the (Re)production of Legal Professional Identity' (2009) 16 Int J Legal Profession 63.

16 UK Social Mobility Commission, 'Unpaid Internships Are Damaging to Social Mobility' (Gov.UK, media release, 23 October 2017), https://www.gov.uk/government/ news/unpaid-internships-are-damaging-to-social-mobility, accessed 30 March 2021.

17 Matthew Taylor, Good Work: The Taylor Review of Modern Working Practices (Department for Business, Energy and Industrial Strategy 2017) 91. 
need for additional regulation of internships - in most cases, 'If a person is obtaining something of value from an internship, [the intern is] most likely to be a worker and entitled to the National Minimum or Living Wage'. ${ }^{18}$ Thus, the issue is one of enforcement, not gaps in legal regulation.

In 2017, a private members' bill passed the UK House of Lords seeking to ban unpaid work experience or internships of more than four weeks in duration, by requiring employers to pay the national minimum wage beyond this period. ${ }^{19}$ The bill did not progress beyond a first reading in the House of Commons. However, HM Revenue \& Customs 'launched a crackdown on unpaid internships' in February 2018, including by sending warning letters to employers in particular sectors, setting up an enforcement team and issuing guidance to employers about their obligations ${ }^{20}$ There are also calls for unpaid internships to be publicly advertised, to increase transparency and reduce reliance on informal networks for recruitment. ${ }^{21}$ Thus, interns are increasingly being recognized as 'workers' in the UK, and may slowly start receiving the same employment rights as other workers, including under equality law.

Fourth, even if individuals can access unpaid work experience, questions are increasingly being raised about the terms and conditions being offered to those involved. In Oliver and others' survey, men (at 26.4 per cent) were significantly more likely than women (at 16.3 per cent) to receive financial compensation during their work experience, including via an allowance or honorarium. Men were also more likely ( 27.4 per cent of respondents) to receive reimbursement for their expenses than women (18.2 per cent of respondents). ${ }^{22}$ It is arguable that this is because men and women tend to do work experience in different industries, which have different normative arrangements around when compensation and reimbursements should be paid to those undertaking work experience. However, in the context of substantial and enduring gender pay gaps in the economy as a whole, it is concerning that women are experiencing a substantial payment gap even in their participation in work experience. Again, this flags important issues for equality and discrimination law, particularly around equal pay.

\section{Ibid.}

Unpaid Work Experience (Prohibition) Bill [HL] 2017-19.

20 Sarah Butler, 'Initiative to Crack Down on Unpaid Internships Launched in UK' The Guardian (London, 9 February 2018), http://www.theguardian.com/society/ 2018/feb/08/initiative-to-crack-down-on-unpaid-internships-launched-in-uk, accessed 30 March 2021.

${ }_{21}$ 'Unpaid Internships and Living Costs "Prevent" Social Mobility' BBC News (London, 30 January 2018), https://www.bbc.com/news/uk-42863951, accessed 30 March 2021.

22 Oliver and others (n 7) 46. 
Fifth, in Oliver and others' survey some respondents, in noting their negative experiences of unpaid work experience, reported that they had experienced discrimination, racism or sexual harassment in the workplace. ${ }^{23}$ This suggests that discrimination law has a substantial role to play in protecting those undertaking unpaid work experience.

\title{
18.3 SCOPE OF EQUALITY LAW
}

Unpaid work experience could variously be described as: work-integrated learning, supervised work experience or practicum placements; volunteering; internships; (unpaid) traineeships; and unpaid trial work. ${ }^{24}$ The various ways in which unpaid work experience might be conceived, and subsequently regulated, poses a particular challenge for the scope of legal regulation. The extent to which unpaid work experience is covered by equality law varies markedly depending on how the work experience itself is viewed.

\subsubsection{Employment Relationship}

If there is an employment relationship, ${ }^{25}$ then the work experience 'employee' is covered by equality law in both the UK and Australia. In the UK, the prohibition of discrimination in section 39 of the Equality Act 2010 (UK) (EqA), as it relates to work, is limited to 'employers' in relation to 'employment'. 'Employment' is defined in the EqA as 'employment under a contract of employment, a contract of apprenticeship or a contract personally to do work' ${ }^{26}$ Unpaid interns in the UK are increasingly being recognized as 'workers', ${ }^{27}$ which forms a third category in UK labour law (together with employees and independent contractors). In Halawi $v$ WDFG UK Ltd, ${ }^{28}$ Arden LJ recognized that EU equality law (which the EqA implements) applies to 'employees' in the extended meaning of that term (that is, it extends to 'workers' as well as 'employees'). ${ }^{29}$ The Court held that, to be covered by EU equality law,

\author{
Ibid 59. \\ Ibid 13. \\ Stewart and Owens (n 2). \\ Equality Act 2010 (UK), s 83; see also s 212(1). In Northern Ireland, see sim-
} ilarly, eg, Employment Equality (Age) Regulations (Northern Ireland) 2006 SI 2006/261, regs 2(3), 7.

27 See eg Hudson v TPG Web Publishing Ltd [2011] UKET 2200565/11.

28 Halawi v WDFG UK Ltd [2014] EWCA Civ 1387, [2015] 1 CMLR 31.

29 Though, in that case, it was held that the claimant was not a worker. See Alysia Blackham, "We Are All Entrepreneurs Now": Options and New Approaches for Adapting Equality Law for the "Gig Economy"' (2018) 34 Int J Comp Lab L \& Indust Rel 413. 
the putative employee must (1) agree personally to perform services, and (2) be subordinate to the employer (that is, generally bound to act on the employer's instructions). ${ }^{30}$ Thus, interns and those completing unpaid work experience may be covered by equality law, if they are classed as 'workers' and perform the work personally. However, as Fredman and Du Toit argue, this is a fragile protection, which may be circumvented by employers 'find[ing] new ways to reconfigure the relationship'. ${ }^{31}$

In Australia, for employees, the adverse action provisions in the Fair Work Act 2009 (Cth) (FWA) prohibit discrimination by 'an employer' against employees or prospective employees on the basis of protected characteristics. ${ }^{32}$ In relation to equality law, the Age Discrimination Act 2004 (Cth) (ADA) section 5 defines 'employment' as including 'part-time and temporary employment' and 'work under a contract for services'. There is a similar definition in the Sex Discrimination Act 1984 (Cth) (SDA) section 4 and the Equal Opportunity Act 1984 (WA) section 4. The definition of 'employee' in the Equal Opportunity Act 2010 (Vic) (EOA) extends to those 'employed under a contract of service' and 'engaged under a contract for services', ${ }^{33}$ but explicitly excludes an unpaid worker or volunteer for the purposes of the Act, except for part 6 which relates to sexual harassment (see further section 18.3.7 in this chapter). Similar provision is made in section 22B of the Anti-Discrimination Act 1977 (NSW), which covers 'workplace participants', including a 'volunteer or unpaid trainee', but only for the purposes of sexual harassment.

Thus, it appears that in the UK, at the federal level in Australia, and in Victoria, Western Australia and New South Wales, it is unlikely that those undertaking unpaid work experience are covered by the same discrimination provisions as regular employees, unless they can establish that an employment relationship is in place ${ }^{34}$ or, in the UK, that they are a 'worker'.

Halawi (n 28) para 4.

31 Sandra Fredman and Darcy Du Toit, 'One Small Step Towards Decent Work: Uber v Aslam in the Court of Appeal' (2019) 48 Indust LJ 260, 273.

32 Fair Work Act 2009 (Cth), s 351(1). 'Employee' and 'employer' are defined in s 335 as having 'their ordinary meanings'.

33 Equal Opportunity Act 2010 (Vic), s 4.

34 See eg the successful claim in GLS v PLP [2013] VCAT 221, [51]. In that case, the claimant was paid at a day rate. 
This limited scope can be compared with the broad coverage of some state and territory legislation in Australia. The Queensland Anti-Discrimination Act 1991 defines 'work' to include:

(e) work under a work experience arrangement within the meaning of the Education (Work Experience) Act 1996, section 4;

(ea) work under a vocational placement;

(f) work on a voluntary or unpaid basis; and ...

(h) work under a guidance program, an apprenticeship training program or other occupational training or retraining program.

'Employment' is defined as including unpaid work in South Australia, ${ }^{35}$ the Australian Capital Territory ${ }^{36}$ and Tasmania; ${ }^{37}$ and 'work' is defined in the Northern Territory to include that 'under a guidance program, vocational training program or other occupational training or retraining program' ${ }^{38}$

The limited scope of equality law at the federal level in Australia would have been resolved to some extent by the proposed (though subsequently abandoned) Human Rights and Anti-Discrimination Bill 2012 (Cth), which would have consolidated the various equality law statutes at the federal level in Australia. The proposed bill would have extended 'employment' to include 'voluntary or unpaid work'. ${ }^{39}$

While there is, at first glance, limited protection offered to those undertaking work experience under equality law, there are other ways of potentially achieving coverage under the various Acts, depending on whether the work experience participant is seen as a volunteer, a prospective employee, undertaking a vocational placement, undertaking unpaid work experience, or perhaps even receiving a service. These options are considered in turn.

\subsubsection{Volunteering}

Oliver and others explicitly exclude volunteering from the scope of 'unpaid work experience', owing to the different benefits involved in each activity: volunteering benefits an altruistic cause while work experience is designed to benefit an individual. ${ }^{40}$ The line between the two, however, is often blurred, meaning it is important to consider the place of volunteers in equality law.

\footnotetext{
35 Equal Opportunity Act 1984 (SA), s 5(1).

36 Discrimination Act 1991 (ACT), dictionary.

37 Anti-Discrimination Act 1998 (Tas), s 3: 'employment or occupation in any capacity, with or without remuneration'.

38 Anti-Discrimination Act 1992 (NT), s 4(1).

39 Human Rights and Anti-Discrimination Bill 2012 (Cth), s 6(1).

40 Oliver and others (n 7) 13.
} 
In Australia, the Fair Work Ombudsman describes a 'genuine volunteering arrangement' as having as its main purpose the benefit of someone (or, perhaps, something) else, where the parties did not intend to enter a legally binding employment relationship, the volunteer is not obliged to attend the workplace or perform work, and the volunteer does not expect to be paid. ${ }^{41}$

If work experience participants are genuine volunteers, then they will not be seen as employees, and do not easily fall within the scope of equality law in most jurisdictions. ${ }^{42}$ Indeed, volunteers are explicitly excluded from the definition of 'employee' in the EOA,${ }^{43}$ except as it relates to sexual harassment (see section 18.3.7 in this chapter).

This has been emphasized in the UK by the Supreme Court decision in $X v$ Mid Sussex Citizens Advice Bureau. ${ }^{44}$ That case considered whether the Disability Discrimination Act 1995 (UK) (which preceded the EqA) applied to volunteers. ${ }^{45}$ The Supreme Court held that equality law only applies to those with a contract of employment; volunteers without contracts are not covered by equality legislation, and a volunteer agreement is not sufficient. ${ }^{46}$

Further, the scope of EU law - and, in particular, the Council Directive 2000/78/EC of 27 November 2000 establishing a general framework for equal treatment in employment and occupation ${ }^{47}$ - is not broader than UK legislation in this context. While the directive covers 'employment' and 'occupation', the Supreme Court held that the reference to 'occupation' in the directive was intended to refer to the 'higher level' concept of 'access to a sector of the

${ }^{41}$ Fair Work Ombudsman, 'Unpaid Work', https://www.fairwork.gov.au/pay/ unpaid-work, accessed 30 March 2021.

42 Though see the broader definitions of 'employment' and 'work' in some Australian states and territories.

43 Equal Opportunity Act 2010 (Vic), s 4.

${ }^{44}$ X v Mid Sussex Citizens Advice Bureau [2012] UKSC 59. For further discussion of the position of volunteers in UK labour law, see Sam Middlemiss, 'The Cost of Kindness: Voluntary Workers and Intern's Rights under Employment Law' [2014] Int J Bus L 130.

45 The Supreme Court did not explicitly consider whether its reasoning also applied to the Equality Act 2010 (UK). However, the definition of employment in the Disability Discrimination Act 1995 (UK), s 68(1) ('employment under a contract of service or of apprenticeship or a contract personally to do work') is substantially similar to that in the Equality Act 2010 (UK), s 83(2) ('employment under a contract of employment, a contract of apprenticeship or a contract personally to do work').

46 Xv Mid Sussex Citizens Advice Bureau (n 44) paras 2, 10.

$47 \quad[2000]$ OJ L303/16. 
market, rather than to particular employment or self-employment' ${ }^{48}$ Thus, the directive might cover:

areas in which a professional qualification of some nature or other is either required or advantageous, or a restrictive condition requires to be satisfied, if a worker is to undertake particular work or to advance in a particular sphere, whether as an employee or on a self-employed basis. They range from, for example, qualification as a doctor or lawyer to possession of a heavy goods vehicle licence. ${ }^{49}$

Access to an occupation or profession generally is covered by the directive; access to a particular post or position of employment is not. Thus, the term 'occupation', read in context, did not extend the scope of the directive to volunteers. Indeed, the European Parliament considered, but ultimately rejected, the possibility of explicitly including unpaid and voluntary work within the scope of the directive. ${ }^{50}$ This was influential in the Supreme Court's reasoning.

This implies, however, that EU equality law may apply to some individuals working without a wage, such as those undertaking vocational training or practical work experience, where that training or work is necessary to obtain access to a profession or occupation. This is developed in section 18.3.4 of this chapter.

\subsubsection{Prospective Employees}

It is evident that prospective employees have some protection under equality law, at least in the making of employment decisions. The EqA section 39(1)(a) makes it unlawful for an employer to discriminate 'in the arrangements [it] makes for deciding to whom to offer employment'. It is also unlawful to victimize a person in those arrangements. ${ }^{51}$ If unpaid work experience (or volunteering) is used as a way of assessing an individual's suitability as a potential employee, then it is likely that those arrangements are covered by equality law.

Similarly, under the FWA section 341(3), a prospective employee 'is taken to have the workplace rights he or she would have if he or she were employed in the prospective employment by the prospective employer'. Further, discrimination and adverse action against prospective employees is prohibited, ${ }^{52}$ at least to the extent that the prospective employer refuses to employ the prospective employee, or discriminates against the prospective employee in the

\footnotetext{
$48 \quad$ Xv Mid Sussex Citizens Advice Bureau (n 44) para 30.

49 Ibid para 29.

50 Ibid paras 39-41.

51 Equality Act 2010 (UK), s 39(3)(a). In Northern Ireland, see similarly, eg, Employment Equality (Age) Regulations (Northern Ireland) 2006 SI 2006/261, reg 7.

52 Fair Work Act 2009 (Cth), s 351.
} 
terms or conditions offered. ${ }^{53}$ While the FWA therefore appears to offer some protection to prospective employees, this is more limited than that under the EqA. Indeed, there is limited scope for interpreting unpaid work experience as falling within the ambit of the FWA.

The prohibition under federal equality law in Australia is closer to that under the EqA. The ADA section 18 makes it unlawful for an employer to discriminate on the basis of age 'in the arrangements made for the purpose of determining who should be offered employment ${ }^{9}{ }^{54}$ Similar provision is made in the SDA section 14(1)(a). Again, as in the UK, it is arguable that this encompasses unpaid work experience, to the extent that it is used to determine whether a worker is suitable for further employment.

The Victorian EOA section 16 also prohibits discrimination against job applicants in determining who should be offered employment; the terms on which employment is offered; refusing or deliberately omitting to offer employment; or denying access to a guidance programme, an apprenticeship training programme, or other occupational training or retraining programme. It is possible that this is also broad enough to capture unpaid work experience.

The key factual debate, however, is whether unpaid work experience is really a way of testing people's suitability for later employment, so that it is part of the 'arrangements ... for deciding to whom to offer employment'. This will vary from case to case. However, Oliver and others' survey found that 27 per cent of respondents were subsequently offered paid employment by the organization in which they undertook unpaid work experience. ${ }^{55}$ This implies that a substantial pool of employers are using unpaid work experience as a way of testing and recruiting employees. Thus, equality law provisions that protect prospective employees may well apply to those undertaking unpaid work experience.

\subsubsection{Vocational Placement}

Unpaid work experience could also be part of an educational programme, including as a formal experience built into a higher education programme of study. The FWA makes explicit provision for 'vocational placements' as a lawfully unpaid form of work, where the person is not regarded as an employee, ${ }^{56}$ and is not entitled to the benefits or entitlements under the FWA. Presumably, someone on a vocational placement would also not be regarded

Ibid s 342 .

Age Discrimination Act 2004 (Cth), s 18(1)(a).

Oliver and others (n 7) 51.

Fair Work Act 2009 (Cth), s 15. 
as a prospective employee. The FWA does not make provision for alternative protections or entitlements for those undertaking vocational placements. However, the restrictive definition of 'vocational placements' in the Act potentially excludes a large number of people undertaking unpaid work experience. Thus, the impact of the vocational placements exception may be limited. ${ }^{57}$

Those undertaking work experience as part of an educational course may, however, be protected by equality law against discrimination by the educational provider itself. For example, the Victorian EOA section 38(2) makes discrimination by an educational authority against a student unlawful in 'denying or limiting access to any benefit provided by the authority' or 'by subjecting the student to any other detriment'. This might include limiting access to any work experience or vocational placement.

The EqA includes a similar provision in the context of further and higher education. Section 91 prohibits discrimination against students in:

- the way education is provided or not provided;

- affording (or not affording) access to a benefit, facility or service; and

- any other detriment.

This is likely to extend to the provision of vocational training as part of an educational programme.

These provisions reflect the broad scope of Council Directive 2000/78/EC of 27 November 2000 establishing a general framework for equal treatment in employment and occupation, ${ }^{58}$ which explicitly prohibits discrimination against those undertaking vocational training. Under article 3(1)(b), the directive applies to 'all persons, as regards both the public and private sectors, including public bodies, in relation to: ... access to all types and to all levels of vocational guidance, vocational training, advanced vocational training and retraining, including practical work experience'. ${ }^{59}$

In $X v$ Mid Sussex Citizens Advice Bureau, the UK Supreme Court noted that the 'intern hoping to learn and impress ... might well fall within article

\footnotetext{
See Stewart and Owens (n 2) 75-82.

[2000] OJ L303/16.
}

59 See similarly Directive 2006/54/EC of the European Parliament and of the Council of 5 July 2006 on the implementation of the principle of equal opportunities and equal treatment of men and women in matters of employment and occupation (recast) [2006] OJ L204/23, art 14(1)(b); Council Directive 2000/43/EC of 29 June 2000 implementing the principle of equal treatment between persons irrespective of racial or ethnic origin [2000] OJ L180/23, art 3(1). 
3(1)(b) ${ }^{60}{ }^{60}$ In Fletcher v Blackpool Fylde \& Wyre Hospitals NHS Trust ${ }^{61}$ this prohibition of discrimination was held to apply to working conditions during training, as well as access to training. Thus, both vocational training and work experience appear to fall within the scope of EU and UK equality law.

\subsubsection{Unpaid Work Experience}

According to the Australian Fair Work Ombudsman, unpaid work experience is acceptable when:

- the person is not doing 'productive' work;

- the main benefit of the arrangement is for the person doing the placement; and

- the person is receiving a meaningful learning experience, training or skill development. ${ }^{62}$

There is limited explicit provision made for unpaid work experience in Australian equality law, though 'unpaid work' generally is covered in some jurisdictions (see section 18.3.1 in this chapter). This may be compared with the EqA, where 'work experience' is protected as part of the regulation of employment service providers. Section 55 of the EqA prohibits employment service providers from discriminating in the provision of an employment service. Under section 56(2), 'provision of an employment service' is defined as including provision of vocational training and vocational guidance, and making arrangements for their provision. Section 56(6) defines 'vocational training' to mean training for employment, or work experience. Discrimination is prohibited in:

- arrangements for selecting persons to whom to offer or provide the service;

- the terms on which the provider offers or provides the service;

- not offering to provide or not providing the service;

- terminating the provision of the service; and

- in relation to any other detriment. ${ }^{63}$

Xv Mid Sussex Citizens Advice Bureau (n 44) para 20.

61 Fletcher $v$ Blackpool Fylde \& Wyre Hospitals NHS Trust [2005] IRLR 689, 705. This view was endorsed in Blackwood v Birmingham \& Solihull Mental Health NHS Foundation Trust [2016] EWCA Civ 607, para 29.

62 Fair Work Ombudsman (n 41).

63 Equality Act 2010 (UK), s 55. 
Harassment and victimization by service providers is also prohibited. ${ }^{64}$ Importantly, service providers also have a duty to make reasonable adjustments, except in relation to the provision of a vocational service. ${ }^{65}$

This regulation of employment service providers, including those providers that offer work experience, could be of fundamental benefit to those undertaking unpaid work experience. The interpretation of these provisions was considered by the UK Court of Appeal in Blackwood v Birmingham \& Solihull Mental Health NHS Foundation Trust ${ }^{66}$ which related to discrimination against a nursing student undertaking a placement in a unit operated by an NHS Trust, as required by her university degree. The student requested shifts that would accommodate her childcare responsibilities; her offer of a placement was subsequently withdrawn by the NHS Trust. The student argued that the withdrawal of her placement was indirect sex discrimination by the NHS Trust.

The Court was asked to consider the jurisdictional point of whether this amounted to discrimination at work (which could be pursued in the Employment Tribunal) or discrimination in education (which had to be pursued in the County Court). ${ }^{67}$ Overturning the Employment Tribunal and Employment Appeal Tribunal, the Court of Appeal held that the Employment Tribunal did have jurisdiction to hear the claim. The Court of Appeal held that, if the student was prevented from making a claim against the NHS Trust, this could potentially create a lacuna in the law, as the discriminatory conduct was allegedly by the NHS Trust in the course of the placement, and not by the university in affording access. ${ }^{68}$ Therefore, sections 55 and 56 needed to be re-formulated to give effect to the directives.

In his decision, Underhill LJ categorized claims in relation to educational placements as being either in relation to access to a placement or occurring in the course of a placement. If the claim is about access, it is primarily a claim against the educational institution, and should be brought in the County Court. However, if the claim is about discrimination by the provider in the course of the placement (here, the NHS Trust), then the provider is potentially liable

\footnotetext{
64 Ibid.

65 Ibid.

66 Blackwood (n 61).

67 This was at issue because s 56(5) states that s 56 'does not apply in relation to training or guidance for students of an institution to which section 91 applies in so far as it is training or guidance to which the governing body of the institution has power to afford access'. Thus, if the prohibition of discrimination in education in s 91 applied, then the student could not proceed under s 55.

68 Blackwood (n 61) paras 43-45.
} 
as a principal under section 55, and the correct forum is the Employment Tribunal. ${ }^{69}$

The case was referred back to the Employment Tribunal to determine the merits of the claim. While section 55 might raise complex jurisdictional points, it offers a significant improvement on existing protection of work experience under federal Australian and Victorian equality law.

\subsubsection{Receipt of a Service}

Even if those undertaking unpaid work experience are not explicitly covered by equality law as employees, volunteers or in their own right, they may still be entitled to protection as recipients of a service. This suggestion was put forward by the GB Equality and Human Rights Commission as a means of protecting volunteers: if they are not employees, then 'it is possible that, when you are providing a volunteering opportunity for someone, this counts as providing them with a service' ${ }^{70}$ While this has not been legally tested, it offers an interesting alternative route for securing protection for those undertaking unpaid work experience, as recipients of a 'work experience service'. This echoes the regulation of employment service providers in the EqA (discussed in section 18.3 .5 of this chapter).

The EqA section 29 provides that the provision of a service to the public or a section of the public - whether for payment or not - must not discriminate:

- by not providing the person with the service;

- in the terms on which the service is provided;

- by terminating the service; or

- by subjecting the recipient to any other detriment.

Harassment and victimization of those who require or receive a service is also unlawful. Further, the duty to make reasonable adjustments applies to a service provider.

The prohibition of discrimination in service provision does not apply to any discrimination that is prohibited as part of the prohibition of discrimination in work. ${ }^{71}$ Thus, it is unlikely to apply to those undertaking work experience,

69 Ibid para 61. See the similar decision in Garrard $v$ Governing Body of the University of London [2013] EqLR 746, where the claimant was held not to be a student, meaning the claim had to be made under s 55 .

70 Equality and Human Rights Commission, 'How Your Organisation Should Treat Volunteers' (19 February 2019), https://www.equalityhumanrights.com/en/advice-and -guidance/how-your-organisation-should-treat-volunteers, accessed 30 March 2021.

71 Equality Act 2010 (UK), s 28. 
as they are likely to be covered by section 55. However, it may open up new avenues for relief for those seen as volunteers.

The issue, though, is whether the provision of work experience or volunteering is really providing a 'service'. In Oliver and others' survey, 14.6 per cent of respondents organized their work experience through an external agency or broker and 12.5 per cent of respondents paid money to a broker, agent or the organization itself to take part in the work experience. ${ }^{72}$ At least in some cases, then, the provision of work experience is almost certainly a 'service', and may involve additional third parties in its provision.

If this hurdle can be overcome, and work experience is regarded as a 'service', this may offer a potential avenue for protection under federal Australian discrimination law as well. For example, the ADA defines 'services' as including 'services of the kind provided by the members of any profession or trade' ${ }^{73}$ This could foreseeably cover many forms of work experience offered by professions and trades. Discrimination in the provision of services, whether for payment or not, is made unlawful by section 28 of the ADA, which prohibits age discrimination in:

- refusing to provide the services;

- terms or conditions on which the services are provided; and

- the manner in which the services are provided.

Similar provision is made in sections 4 and 22 of the SDA.

The potential for volunteers to be protected as recipients of a service is explicitly acknowledged by the Victorian Equal Opportunity and Human Rights Commission (VEOHRC) in the context of the EOA. ${ }^{74}$ Section 4 of the EOA defines 'services' as including 'services of any profession, trade or business, including those of an employment agent', but does not include education and training in an educational institution. The EOA prohibits discrimination in service provision, whether or not for payment:

- by refusing to provide a service;

- in the terms on which the service is provided; and

- by imposing any other detriment. ${ }^{75}$

Oliver and others (n 7) 36, 45.

Age Discrimination Act 2004 (Cth), s 5.

74 VEOHRC, Volunteers and the Equal Opportunity Act 2010: Discrimination Fact Sheet (VEOHRC 2011).

75 Equal Opportunity Act 2010 (Vic), s 44. 
Sexual harassment in the provision of services is also prohibited. ${ }^{76}$ According to the VEOHRC, an organization offering a volunteering opportunity may be providing a 'service' to their volunteers where it has a structured volunteering programme, and the volunteer is required to undertake training or skill development before volunteering, or the volunteer undertakes an assessment, gains an accreditation or gains professional experience as part of their volunteering. ${ }^{77}$ These broad requirements could encompass many forms of unpaid work experience.

\subsubsection{Sexual Harassment}

In some jurisdictions, protection against sexual harassment is broad enough to encompass those undertaking unpaid work experience, even if they are not entitled to the protection of equality law generally.

Under the SDA, it is unlawful 'for a workplace participant to sexually harass another workplace participant at a place that is a workplace of either or both of those persons' ${ }^{78}$ However, 'workplace participant' is defined narrowly to include an employer or employee, commission agent or contract worker, or partner in a partnership..$^{79}$ This is unlikely to assist those participating in unpaid work experience. However, the SDA also prohibits sexual harassment in the provision of services; ${ }^{80}$ if the provision of work experience is a 'service' then sexual harassment may well be prohibited by federal discrimination law.

The Victorian EOA explicitly extends protection from sexual harassment to 'an unpaid worker or volunteer' as if they were an employee.$^{81}$ Further, the EOA offers broad protection from sexual harassment through the prohibition of harassment in 'common workplaces'. Under section 94, 'A person must not sexually harass another person at a place that is a workplace of both of them'. This applies whether or not they are both employees, or employed by the same or different employers. ${ }^{82}$ 'Workplace' is defined broadly as 'any place where a person attends for the purpose of carrying out any functions in relation to his or her employment, occupation, business, trade or profession and need not be a person's principal place of business or employment'. Again, this appears broad enough to encompass those undertaking unpaid work

Ibid s 99.

VEOHRC (n 74).

Sex Discrimination Act 1984 (Cth), s 28B(6).

Ibid s 28B(7).

Ibid s 28G.

81 See the definition of 'employee', 'employer' and 'employment' in Equal Opportunity Act 2010 (Vic), s 4.

82 Ibid s 94(2). 
experience or internships. Similar provision is made in section 22B of the Anti-Discrimination Act 1977 (NSW), which covers 'workplace participants', including a 'volunteer or unpaid trainee', but only for the purposes of sexual harassment.

\subsubsection{Reasonable Adjustments}

The EqA extends the duty to make reasonable adjustments to employment service providers, except in relation to the provision of a vocational service. ${ }^{83}$ This, then, imposes a duty to make reasonable adjustments on those providing vocational training and work experience.

The situation in Australia is less clear cut. The Disability Discrimination Act 1992 (Cth) builds the provision of reasonable adjustments into the definition of disability discrimination; that is, it is direct discrimination to not make reasonable adjustments if the failure to do so means the person is treated less favourably. ${ }^{84}$ Further, the inherent requirements exception for disability discrimination in employment only applies if, 'because of the disability, the aggrieved person would be unable to carry out the inherent requirements of the particular work, even if the relevant employer, principal or partnership made reasonable adjustments for the aggrieved person'. ${ }^{85}$ Thus, reasonable adjustments are limited to those covered by the prohibition of disability discrimination, namely, those in 'employment', ${ }^{86}$ education ${ }^{87}$ and accessing services. ${ }^{88}$ Given the Disability Discrimination Act adopts a limited definition of employment, ${ }^{89}$ similar to other federal discrimination statutes, those undertaking unpaid work experience will only have an entitlement to reasonable adjustments if they can establish that they are an employee, in education or receiving a service. Thus, the above-mentioned considerations are likely to apply to those seeking reasonable adjustments as well.

\subsection{DISCUSSION}

In summary, equality law offers a patchwork of rights that have the potential to protect those undertaking unpaid work experience. It is likely that unpaid work experience is covered in at least some way, and potentially multiple

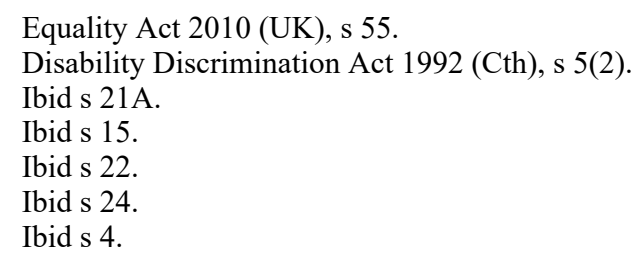


overlapping ways, in each jurisdiction. However, as this discussion has shown, there are different ways in which unpaid work experience can be conceived, and different legal models for protecting those undertaking this type of work. More particularly, unpaid work experience could be covered by:

- conceiving of work experience participants as 'employees' or 'workers';

- viewing unpaid work experience as part of the process of recruitment, making participants prospective employees;

- expanding the definition of 'work' or 'employment' to include unpaid or voluntary work (as in some Australian states and territories, including in the area of sexual harassment);

- prohibiting discrimination in education; and/or

- regulating unpaid work experience as a service, either specifically (as in the UK) or as a service generally (as in Australia). ${ }^{90}$

The complexity of this legal coverage makes the enforcement of equality law particularly fraught in this context. Those participating in unpaid work experience are unlikely to be able to navigate this complex array of (potential) rights without costly legal assistance. This is something they are particularly ill-equipped to obtain, given the unpaid nature of many positions. Thus, legal reform becomes particularly important in this context, to ensure that rights are clear and capable of enforcement.

The most straightforward way of resolving this difficulty would be to explicitly amend the definition of 'employment' or 'work' to include unpaid work and volunteers within the scope of equality law, as has occurred in some Australian states and territories. Given the fundamental importance of unpaid work experience in securing transitions to employment, it is desirable from a normative perspective that discrimination law encompass this form of work. The potential repercussions of not protecting unpaid work experience - for social mobility, inclusion of non-traditional workers and addressing the gender pay gap - make this type of reform a key priority.

Accompanying this, however, there needs to be a greater focus on enforcement, to ensure work experience participants can be assisted and encouraged to assert their rights. As I have explored elsewhere, young workers rarely assert their rights under age discrimination law. ${ }^{91}$ Those undertaking unpaid work experience are even less likely to pursue legal redress, especially given

90 Cf the approach of labour law generally: Rosemary Owens and Andrew Stewart, 'Regulating for Decent Work Experience: Meeting the Challenge of the Rise of the Intern' (2016) 155 Int Lab Rev 679, 688.

91 Alysia Blackham, 'Why Do Employment Age Discrimination Cases Fail? An Analysis of Australian Case Law' (2020) 42 Syd L Rev 1. 
the costs of exit and finding a new work experience position are likely to be far lower than those of pursuing legal avenues. As in the UK, then, there is a need for government agencies to proactively assert the rights of those undertaking unpaid work experience. The activities of HM Revenue \& Customs - in sending warning letters to employers in particular sectors, setting up an enforcement team and issuing guidance to employers about their obligations ${ }^{92}$ - are a step in the right direction, but will need to be rigorously pursued in the future to be effective. Extending this action to equality law is likely to be a challenge for the GB Equality and Human Rights Commission, given its already stretched budget and mandate. In Australia, this is an area that could be well managed by the Fair Work Ombudsman, with appropriate additional resourcing. However, legal reform to bring unpaid work experience within the scope of the FWA adverse action provisions is a necessary first step for this to be effective.

\subsection{CONCLUSION}

Unpaid work experience is likely to be an issue of growing significance in the years to come. While there are moves in the UK to recognize all unpaid interns as workers - entitled to the national minimum wage and the protection of equality law - the trend in Australia is to exclude unpaid work experience from legal protection, at least at the federal level. Unpaid work experience raises substantial challenges to equality and social inclusion, particularly in the need for reasonable adjustments, addressing power imbalances, promoting social mobility and remedying the gender pay gap. The inherent complexity of unpaid work experience, which can be conceived of in multiple ways within the legal framework, has led to a patchwork of (potential) legal coverage under equality law. The challenge for law-makers and policy-makers now is to clarify and simplify this legal regime, in a way that makes room for more effective enforcement of equality rights.

92 Butler (n 20). 